Derleme/Review

\title{
Statinlerin nöroloji pratiğindeki yeri
}

Role of statins in the practice of clinic neurology

Yakup Türkel*, Murat Terzi

Ondokuz Mayıs Üniversitesi Tıp Fakültesi Nöroloji Anabilim Dalı, Samsun

\begin{tabular}{|c|c|}
\hline \multicolumn{2}{|c|}{ MAKALE BİLGİLERİ } \\
\hline \multicolumn{2}{|c|}{ Makale Geçmişi: } \\
\hline Geliş & $23 / 01 / 2009$ \\
\hline Kabul & 15 / 03 / 2010 \\
\hline \multicolumn{2}{|c|}{ * Yazışma Adresi: } \\
\hline \multicolumn{2}{|c|}{ Yakup Türkel } \\
\hline \multicolumn{2}{|c|}{ Ondokuz Mayıs Üniversi } \\
\hline \multicolumn{2}{|c|}{ Nöroloji Anabilim Dalı } \\
\hline \multicolumn{2}{|c|}{55139 Kurupelit, SAMSUN } \\
\hline E-post & @omu.edu.tr \\
\hline
\end{tabular}

\section{Anahtar Kelimeler: \\ Statin \\ HMG-CoA Redüktaz \\ Hiperlipidemi \\ Kolesterol \\ Nöroloji \\ Tedavi}

\section{Key Words :}

Statin

HMG-COA Reductase

Hyperlipidemia

Cholesterol

Neurology

Treatment

\section{ÖZET}

Statinler, 3-hidroksi-3-metilglutaril koenzim A (HMG-CoA) redüktaz inhibisyonu sayesinde karaciğerde hücre içerisinde LDL-kolesterol seviyesinde azalma sağlarlar. Bu durum karaciğer hücre yüzeyindeki LDL reseptör sayısının artmasına, dolayısıyla plazma LDL seviyelerinin düşmesine neden olur. Ayrıca statinler LDL'nin periferden absorbsiyonunu artırarak karaciğer hücrelerine ve diğer hücrelere girişini ve orada yıkımını artırarak kolesterol seviyesini azaltırlar.

Statinlerin kolesterol düşürücü etkilerinin yanı sıra inflamasyon ve oksidasyon, hücre proliferasyonu, endotel fonksiyonları, koagülasyon ve trombosit sistemi üzerine de etkili olduğu gösterilmiştir.

Kolesterol artışı ile koroner arter hastalığı arasında ilişki olduğu ve aynı zamanda kolesterol düşürücü tedavinin koroner arter hastalığının önlenmesi ve tedavisindeki önemi değişik çalışmalarla ortaya konmuştur. Benzer mekanizmalarla hiperkolesteroleminin inmede rol oynadığı gösterilmiştir. Bunun dışında multiple skleroz, demans gibi inme dışındaki nörolojik hastalıkların etyolojisinde hiperkolesteroleminin oynadığı rol son zamanlarda araştırılmaya başlanmıştır. Tüm bu çalışmaların sonunda statinlerin nörolojik hastalıklarda kullanımıyla ilgili daha fazla randomize, kontrollü çalışmaya ihtiyaç olduğu sonucuna varılmıştır.

J. Exp. Clin. Med., 2009; 26:55-61

\begin{abstract}
Statins reduce the level of LDL-cholesterol in liver cells by inhibiting 3-hydroxy 3-methylglutaryl coenzyme A (HMG-COA) reductase. This causes an increase of the number of the LDL receptors located on liver cell surfaces and thus there is a decrease in plasma LDL levels. Statins also cause an increase in the peripheral absorbtion of LDL and more LDL enters liver cells where it is destructed causing a reduction in cholesterol levels.

Besides their cholesterol reducing effects, statins have been assessed as having functions in inflamation and oxidation, cell proliferation, endothelial functions, coagulation and platelet systems.

Various studies have put forward a relationship between cholesterol increase and coronory artery disease. It has also been documented that cholesterol reducing therapy is important in the preventation and cure of coronory artery disease. Using similar mechanisms, it has also been shown that hypercholesterolemia also plays an important role in the evalation of stroke.

Recently, studies investigating the role of hypercholesterolemia in the etiologies of neurological diseases other than stroke such as multiple sclerosis and dementia have been designed also. Results of studies concerning the usage of statins in neurological diseases have led to a conclusion that more randomised and controlled studies are needed.

J. Exp. Clin. Med., 2009; 26:55-61
\end{abstract}

(C) 2009 OMÜ Tüm Hakları Saklıdır.

\section{Giriş}

Oral olarak kullanılan statinler etkisini 3-hidroksi3-metilglutaril koenzim A (HMG-CoA) redüktaz enzimini kompetetif olarak inhibe ederek gösterirler (Gaw, 2004)
(Şekil 1). Bu enzim inhibisyonuyla karaciğerde hücre içerisinde LDL-kolesterol seviyesinde azalma olur. $\mathrm{Bu}$ etki karaciğer hücre yüzeyindeki LDL reseptör sayısının artmasına, dolayısıyla plazma LDL seviyelerinin düşmesine 
neden olur. Ayrica statinler LDL'nin periferden absorbsiyonunu artırarak karaciğer hücrelerine ve diğer hücrelere girişini ve orada yıkımını artırarak kolesterol seviyesini düşürürler (Delanty ve Vaughan, 1997; Kayaalp, 1998; Cucchiara ve Kasner, 2001). Statinlerin kolesterol düşürücü etkilerinin yanı sıra inflamasyon ve oksidasyon, hücre proliferasyonu, endotel fonksiyonları, koagülasyon ve trombosit sistemi üzerine de etkili olduğu gösterilmiştir (Grundy, 1998; Takemoto ve Liao, 2001; Gaw, 2004).

\section{Statinlerin inflamasyon ve oksidasyon üzerine etkileri:}

Makrofajlar tarafindan intimada kolesterol alınması ve sentezlenmesi sonucu bu hücreler içinde kolesterol birikmesine bağlı köpük hücreleri oluşur. Bunun yanında aktive makrofajlar tarafindan salınan metalloproteinazlar; ekstrasellüer matriks yıkımına ve fibröz kapsülün zayıflatılmasına yol açarak plak rüptürünü artırırlar (Delanty ve Vaughan, 1997; Liao, 2002). Statin tedavisi ile aterosklerotik plaklar içinde inflamatuvar hücrelerin (T lenfosit, makrofaj), lipid miktarının ve makrofajlar tarafından salınan matriks metalloproteinaz ekspresyonunun azaldığ 1 , kollajen lif sayısının arttığı, LDL oksidasyonun engellendiği ve okside LDL'nin makrofajlar tarafından alınmas1nın inhibe olduğu, makrofaj aktivitesinin ve köpük hücresi oluşumunun azaldığı gösterilmiştir (Vaughan ve ark., 1998; Rosenson ve Tangey, 1998; Cucchiara ve Kasner, 2001; Liao, 2002). Statinler; lipid çekirdeği, lipid oksidasyonu, inflamasyonu, matriks metalloproteinaz-2 ve hücre ölümünü azaltarak, metalloproteinaz-1 doku inhibitörünü ve kollajen içeriğini artırarak plak stabilizasyonunda görev alırlar. Fibriler kollajende artma ise fibröz kapsülün sağlamlığınına katkıda bulunur (Takemoto ve Liao, 2001; Liao, 2002).

Statin tedavisi ile endotelde bulunan intrasellüler adhezyon molekülü (ICAM-1), monosit yüzey reseptörü CD11b ekspresyonu azalmıştır. Statin tedavisi ile adhezyon molekülü P-selektin ekspresyonun azalması sonucu, lökosit-endotel etkileşimi ve nötrofillerin endotele adhezyonu azalmaktadır (Vaughan ve Delanty, 1999; Cucchiara ve Kasner, 2001; Liao, 2002). Sitokinler doku faktörü ekspresyonunu ve platelet aktive edici faktör oluşumunu artırmasi ile trombogenezisi artırırlar. Statinler bu sitokinlerin astrosit ve makrofajlardan ekspresyonunu baskılarlar (Rosenson ve Tangey, 1998; Vaughan ve Delanty, 1999; Cucchiara ve Kasner, 2001).

\section{Statinlerin hücre proliferasyonu üzerine etkileri:}

Aterosklerotik plak oluşumunda vasküler düz kas hücresi proliferasyonu ve farklılaşması önemli rol oynar. Pravastatin dışındaki statinler vasküler düz kas hücrelerinin proliferasyonunu ve migrasyonunu engeller ve apoptozunu hızlandırırlar. Düz kas hücresi proliferasyonunu engellemeleri mevalonat sentezini azaltmaları sonucu görülmektedir. Düz kas hücreleri üzerine olan bu etkileri ile plak gelişimini ve yeni plak oluşumunu bozmaktadırlar (Delanty ve Vaughan, 1997; Vaughan ve ark., 1998; Takemoto ve Liao, 2001; Liao, 2002).

\section{Statinlerin endotel fonksiyonları üzerine etkileri:}

Endotelyal nitrik oksit sentetaz (eNOS) ile oluşan nitrik oksit (NO) damar endotelinin vazomotor tonusunun düzenlenmesi, trombosit agregasyonu ve adhezyonunun inhibisyonu ve fibrinolizisi artırıcı etkiye sahiptir (Rosenson ve Tangey, 1998; Vaughan ve Delanty, 1999; Cucchiara ve Kasner, 2001; Takemoto ve Liao, 2001). eNOS geni silinmiş farelerde daha büyük serebral hasar görülmektedir. Statinler, mevalonat ve izoprenoid sentezini azaltarak eNOS ekspresyonunu artırır. Farelerde orta serebral arter tıkanmasindan sonrası statin tedavisi ile serebral kan ak1mının artıtığı ve bunun eNOS ekspresyonun artışı ile korele olduğu görülmüştür (Delanty ve Vaughan, 1997; Rosenson ve Tangey, 1998; Vaughan ve Delanty, 1999; Takemoto ve Liao, 2001; Liao, 2002).

\section{Statinlerin trombosit ve koagülasyon üzerine etkileri:}

Statin tedavisi ile trombin-antitrombin III kompleksinde, fibrinopepetid A ve trombomodulin düzeyinde normale dönme, tromboksan A2 düzeyinde ve trombosit agregasyonunda azalma, prostosiklin düzeyinde artma bulunmuştur (Delanty ve Vaughan, 1997; Vaughan ve ark., 1998; Takemoto ve Liao, 2001; Liao, 2002). Statin tedavisi ile plazminojen aktivatör inhibitör tip-1 düzeylerinin azaldığı, doku plazminojen aktivatörü seviyesinin arttığ 1 ve buna bağlı fibrinolizisin arttığ gözlemlenmiştir (Delanty ve Vaughan, 1997; Vaughan ve ark., 1998; Cucchiara ve Kasner, 2001; Takemoto ve Liao, 2001; Liao, 2002).

\section{Statin alt tiplerinin farmokinetik özellikleri:}

Statin alt tiplerinin farklı kimyasal yapıya sahip olmaları farmokokinetik açıdan farklılıklara neden olmaktadır. En başta, pravastatin ve rosuvastatininin tek suda çözünebilir statinler, atorvastatin ve rosuvastatininin ise en uzun plazma yarı ömrüne (Sirasıyla 14,19 saat) sahip statinler oldukları vurgulanmalıdır. Bunun dişında, pravastatinin aktif metaboliti yoktur. Pravastatin ve rosuvastatin dışındakiler lipofiliktir. Proteine bağlanma yüzdesi en düşük olan pravastatindir (\%50) (Gaw, 2004).

\section{Statinlerin yan etkiler:}

Gastrointestinal huzursuzluk, baş ağrısı, yorgunluk, deri döküntüleri sıklıkla görülebilen ve çok rahatsız etmeyen yan etkilerindendir. Bununla birlikte iki tane çok önemli ve çok sık görülmeyen yan etkisi bulunmaktadır. Birincisi karaciğer enzimi üzerine etkisidir ki genellikle hasta tarafindan fark edilmez ancak enzim takibine gerek duyulabilir ve değerler ilaç kesildiğinde bile laboratuvar referans aralığı üst limitinin üç katından fazlasına çıkabilir (Gaw, 2004). 
Çok sık rastlanmayan ikinci yan etki ise, statinlerin bazen kas fonksiyonunu etkileyerek ağr1, güçsüzlük ve kas enzimi olan kreatin kinazın (CK) kan dolaşımına sızmasına neden olabilmesidir. Bu kas hasarının bir belirleyicisidir ve laboratuar referans aralığının üst sınırlarını on kat aştığında ilaç kesilmesi gerekir. Bu statine bağlı miyopatinin en aşırı tipinde rabdomiyoliz gelişebilir. $\mathrm{Bu}$ 2001 yılında klinik uygulamadan kaldırılan serivastatinde en s1k görülmüştür.

\section{İlaç etkileşimleri:}

Statinler ağırlıklı olarak sitokrom P450 sistemi tarafında karaciğerde metabolize edildiğinden bu düzeyde bir ilaç etkileşimi beklenmektedir. Pravastatin ve rosuvastatinin suda çözünürlügü nedeniyle, büyük ölçüde karaciğerde metabolize edilmezler ve bu yüzden diğer statinlere oranla ilaç etkileşimlerinin oranı daha düşüktür. Bu özellik, hastaların statin tedavisi ile birden fazla ilaç aldığında önem kazanabilir (Gaw, 2004).

\section{Statinler ve İnme}

\section{Statinlerin nöroloji pratiğinde kullanımı}

Artmış kolesterol düzeyleri ile iskemik inme arasında pozitif bir ilişki olduğu ve artmış kolesterol seviyesinin iskemik inmeye bağlı mortaliteyi anlamlı ölçüde artırdığı gösterilmiştir. Hiperkolesteroleminin inmeli hastaların $\% 24,5$ 'inde, aterotromboza yatkın olguların \%27,9'unda, laküner inmeli olguların \%32,1'inde, sağlıklı kontrol grubunun ise \%14,3'ünde bulunduğu gösterilmiştir (Iso ve ark., 1989; Hachinski ve ark., 1996; Eastern Stroke and Coronary Heart Disease Collaborative Research Group, 1998). Küçük arterlerin media tabakasında lipid birikimi olan lipohiyalinozisin varlığı, lipit anormalliğinin küçük arter hastalığında önemli olduğunu göstermiştir (Amarenco, 2001). Bir başka meta analizde ise, kolesterol artışı ile inme arasında pozitif ilişki gösterilememiştir (Prospective studies collaborations, 1995). Gözlemsel çalışmaların yetersizliğinin nedeni kolesterol artışı ile inme arasındaki ilişkiyi araştıran çalışmaların koroner arter hastalığı (KAH) ile yapılan araştırmaların içinde olmasıdır. KAH inmeye

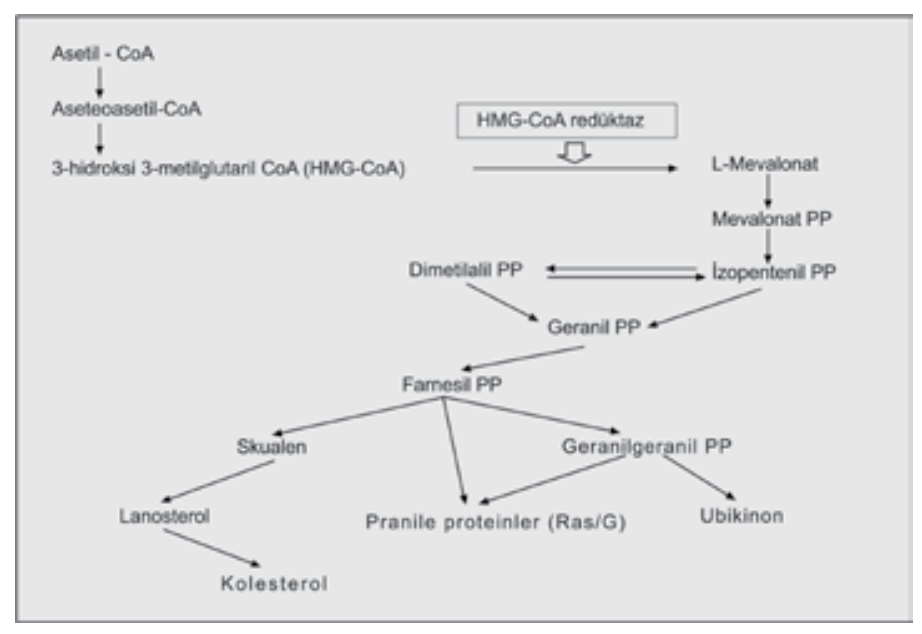

Şekil 1. Statinlerin sentezi göre daha genç yaşlarda görülmektedir. Bu yaşlarda aterosklerotik nedenli inme nadir görülmektedir (Blauw ve ark., 1997; Amarenco, 2001). Yine aynı çalışmaların uzun dönem takibi bulunmamaktadır.

Statinler iskemik inmenin tüm tiplerinde etkilidir. Statinlerin yararlı etkileri kolesterolü düşürmenin yanı sıra daha önce bahsedilen plak stabilizasyonu, inflamasyonun süpresyonu, endotel fonksiyonunun düzeltilmesi gibi etkilerden kaynaklanmaktadır (Blauw ve ark., 1997; Amarenco, 2001). Kolesterolün düşürülmesi küçük arterlerdeki laküner infarktların önlenmesinde önemli etkiye sahiptir (Plehn ve ark., 1999; Liao, 2002).

Statinlerin inmedeki öneminin vurgulandığ 1 çeşitli klinik çalışmalar vardır (Tablo 1).

Tablo 1. Statinlerin inme hastalarındaki önemini araştıran klinik çalışmalar

\begin{tabular}{|l|l|c|c|c|c|c|c|}
\hline Çalışma adı & İlaç & $\begin{array}{l}\text { Doz } \\
(\mathrm{mg} / \text { gün }\end{array}$ & $\begin{array}{l}\text { Hasta } \\
\text { Sayı1 } 1\end{array}$ & $\begin{array}{l}\text { Ortalama } \\
\text { Yaş }\end{array}$ & $\begin{array}{l}\text { Erkek } \\
\text { Cinsiyet (\%) }\end{array}$ & $\begin{array}{l}\text { İlem } \\
\text { Süresi y1l }\end{array}$ & $\begin{array}{l}\text { Immede } \\
\text { RRA(\%) }\end{array}$ \\
\hline 4S & Simvastatin & $10-40$ & 4444 & $35-70$ & 81 & 5.4 & 30 \\
\hline WOSCOP & Pravastatin & 40 & 6596 & $45-64$ & 100 & 4.9 & 11 \\
\hline CARE & Pravastatin & 40 & 4159 & $21-75$ & 86 & 4.8 & 31 \\
\hline KLIS & Pravastatin & 40 & 9014 & $31-75$ & 83 & 6.1 & 19 \\
\hline MIRACL & Atorvastatin & 80 & 3086 & 65 & 65 & 0.34 & 50 \\
\hline GREACE & Atorvastatin & $10-80$ & 1600 & 58 & 78 & 3 & 47 \\
\hline HPS & Simvastatin & 40 & 20536 & $50-80$ & 75 & 5 & 25 \\
\hline PROSPER & Pravastatin & 40 & 5804 & $70-82$ & 48 & 3.2 & 3 \\
\hline ALLHAT-LTT & Pravastatin & 40 & 10355 & 66 & 51 & 4.8 & 9 \\
\hline ASCOT & Atorvastatin & 10 & 19342 & $40-79$ & 81 & 5 & 25 \\
\hline CARDS & Atorvastatin & 10 & 2838 & $40-75$ & 68 & 3.9 & 48 \\
\hline ALLIANCE & Atorvastatin & $10-80$ & 2443 & $31-78$ & 82 & 4.3 & 13 \\
\hline TIMI22 & Pravastatin & 40 & 4162 & 58 & 78 & 2 & -9 \\
\hline TNT & Atorvastatin & 10 & 10001 & 61 & 81 & 4.9 & 25 \\
\hline İDEAL & Atorvastatin & 80 & 8888 & 62 & 81 & 4.8 & 13 \\
\hline İDEAL & Atorvastatin & 80 & 8888 & 62 & 81 & 4.8 & 13 \\
\hline
\end{tabular}

Tablo 1 : RRA: Relatif risk azalması, 4S:The Scandinavian Simvastatin Survival Study, WOSCOP: The West scotland Coronery Preventetion, CARE: The cholesterol and recurrent event, LIPID: The longterm intervention with pravastatin in ischemic disease, KLIS: The Kyushu lipid interventional study, MIRACL: The myocardial ischemia reduction with aggresive cholesterol loveryl, GREACE: in the Greek atorvastatin and coronary heart disease evaluation, HPS: The heart protection study, PROSPER: The Pravastatin Elderly İndividuals at risk of vascular disease study, ALLHAT-LTT: The antihypertensive and lipid-lowering treatment to prevent attact heart trial, ASCOT: In the Angolo-scandinavian cardiac outcomes trial, CARDS: In the Collaborative atorvastatin diabetic study, ALLIANCE: The 4 year aggressive lipid-lowering initation abates new cardiac events, TIMI22: The pravastatin or atorvastatin evalutaion and infection therapy-trombolyis in myocarfial infarction 22, TNT: In the treating to new targets, IDEAL: The incremental decrease in endpoint through aggresive lipid lowery.

\section{Sekonder koruma çalışmaları:}

The Stroke Prevention by Aggressive Reduction in Cholesterol Levels (SPARCL) çalıșması koroner arter hastalığ1 öyküsü olmayan hastalarda inme riskinde statinlerin etkileri hakkında yapılan ilk araştırmadır. Bu çift kör, randomize, plasebo kontrollü, çok merkezli çalışmada özel serebrovasküler son noktalarda agresif atorvastatin tedavisinin (80 mg/gün ) etkileri araştırılmıştır. Hastalar, KAH'na ait bir bulgu yoksa ve daha önceden bir geçici iskemik atak (TİA) veya inme geçirmişlerse, LDL seviye- 
leri $100-190 \mathrm{mg} / \mathrm{dl}$ arasındaysa çalışmaya alınmış. Primer klinik son noktalar, ölümcül ya da ölümcül olmayan olmayan inmenin ilk oluş zamanıydı. Bu çalışmada son altı ay içerisinde bir inme veya TİA geçirmiş 4731 hasta rastgele seçilmiştir. 6 yıl tamamlandığında, kontrol grubundakilerin 265's1 ölümcül veya ölümcül olmayan inme geçirmiştir. Atorvastatinle, ilk inme oluşumunda riskte \%16 azalma görülmüştür. İnme veya TİA'da ikinci son nokta zamanı için, kontrol grubunda 476 ve atorvastatin grubunda 375 hadise ile riskte $\% 23$ düşüş olduğu görülmüştür (SPARCL Investigators, 2006).

Heart Protection Study (HPS) çalışması, KAH'1 tespit edilmeyen 1820 inmeli, randomizasyondan önce inmeli 3820 hastayı kapsamaktaydı. KAH'1 olmayan 1820 hastada major vasküler olaylardaki düşüş \%23'tü. Bu sonuçların yorumlanmasında bazı şüpheler vardı. $\mathrm{Bu}$ son noktalar (major koroner olay, inme veya revaskülarizasyon) tamamıla major koroner olayların azalması ve revaskülarizasyon nedeniyleydi, çünkü simvastatin grubunda $\% 10,4$ ve plasebo grubunda $\% 10,5$ tekrarlayan inmeler vardı. Simvastatinin inme rekürrensi üzerine etkisizliği şans eseri olarak (subgrup analizleri) veya aslında rekürren inmeli az sayıdaki hastayla prespesifik analiz yapılamamas1 ve dolayısıyla bir farkı belirlemedeki zayıf etkinliğine bağlı olabilir (Heart Protection Study Collaborative Group, 2004).

$\mathrm{Bu}$ çalışmaların istatiksel analizi yapıldığında, statinler rekürren inmede neredeyse önemsiz bir farkla ilişkili olduğu major vasküler olayların oluşmasında ise önemli bir farkla ilişkili olduğu görülmektedir.

\section{Statinler ve serebral hemoraji}

Daha önceki çalışmalarda serum kolesterol seviyesinin düşürülmesi ile hemorajik inmenin artması arasında bir ilişki olduğu belirtilmiştir (Yano ve ark., 1989). Kolesterol düzeyinin $160 \mathrm{mg} / \mathrm{dl}$ altına düşmesi ve diastolik kan basıncının $90 \mathrm{mmHg}$ üzerine çıkması hemorajik inmeye bağlı mortalitede anlamlı derecede artmaya neden olduğu belirtilmiştir (Iso ve ark., 1989). Düşük kolesterol düzeyinin intraserebral arterlerde endoteli zayiflatarak, hipertansiyon varlığında hemorajiyi artırdığ düşünülmektedir. Hücre membranındaki kolesterol miktarının azalması sonucu eritrosit osmotik frajilitesinin arttığ gösterilmiştir (Iso ve ark., 1989).

CARE çalışmasında ortalama kolesterol seviyesi 167 mg düzeyine inmesine karşın hemorajik inmede bir artma görülmemiştir (Plehn ve ark., 1999). Statin çalışmalarının meta analizinde başlangıç kolesterol düzeyi, kolesterol düzeyindeki değişiklikler ile serebral hemoraji arasında bir ilişki bulunamamıştır (Warshafsky ve ark., 1999).

\section{Statinler ve Demans}

Santral sinir sistemi (SSS)'de kolesterol döngüsü yaklaşık $0.09 \mathrm{mg} /$ dakika/kilogram olup bu vücudun diğer kısımlarına göre $120 \mathrm{kez}$ daha hızlıdır (Björkhem ve ark., 1998). Plazmada yüksek kolesterolün varlığı, SSS'ne girdiği bilinen statinler ve kolesterolün SSS'den atılımını kısmen bloke eden 24 hidroksilazın yokluğu, beyindeki sterol döngüsünü değiştirebilir (Haley, 2000). Nöron hücresinin ve miyelin dokusunun şekillenmesi sırasında, beyindeki kolesterolün iç döngüsü SSS'de oluşan iki protein sistemi ile ilgilidir. Bunlar düşük dansiteli lipoprotein reseptör ailesinin çeşitli üyeleri ve apolipoprotein E'nin (APOE 3) isoformudur (Bales ve ark., 1999). Yapılan çalışmalar göstermiştir ki SSS içindeki APOE'nin miktarı, tipi ve beyne giren sterol miktarı ile Alzheimer hastalığındaki (AH) nöritik plak formasyon hızı arasında direkt bir ilişki vardır (Evans ve ark., 2000).

Amiloid $\mathrm{A} \beta$ peptid, Alzheimer hastalığının patolojik göstergelerinden biri olan senil plakların ana elementidir. Bu amiloid formun fibriler formudur (Simons ve ark., 2000). Diyetteki yüksek lipid plazmadaki kolesterol konsantrasyonunu arttırarak, sadece kandaki değil SSS'deki APOE konsantrasyonunu da arttırır. Bu ise beyindeki sterol döngüsünü ve $A \beta$ üretim hızını arttırarak nöritik plak formasyonu arttırır (Kalmijn ve ark., 1996).

En son yapilan retrospektif epidemiyolojik çalışmalarda statinlerin kullanımı ile demans prevalansının \%70'e kadar azaldığı gösterilmiştir (Vaughan ve ark., 2001; TenDam ve ark., 2001; Rockwood ve ark., 2002). $\mathrm{Bu}$ da bu ilaçların AH için koruyucu olabileceği görüşünü gündeme getirmiştir. Bununla birlikte bu endikasyonun demansda geçerli olup olmayacağ tartışması da sürmektedir. Son dönemde statinlerin etksinin ne olduğunu göstermeye yönelik çalışmalar yapılmıştır. Hücre kültür çalışmalarında, kolesterol düşürücü ilaçlarla tedavinin nöronlarda ve daha sonra da beyin dokusunda $\mathrm{A} \beta$ pepdid üretimini azalttığ 1 şeklindedir (Rockwood ve ark., 2002). Ancak hala kolesterolün nasıl olup da $A \beta$ birikiminin oluşumunu sağlayabildiği tartışılmaktadır.

Ek olarak hücresel kolesterolün azalması, $A \beta$ 'nın daha sonraki dönemde fibril formasyonunu oluşturabilme yeteneğini \%50 civarında azaltabilir. Diğer çarpıcı bir bulgu statinlerin presenilin 1 aktivitesinin stabilizasyonunu değiştirdiği ile ilgilidir. Bu ise preseniline bağlı sekretaz aktivitesini direkt olarak etkiler (Frears ve ark., 1999).

Yapılan çalışmalarda gösterilmiştir ki, lovastatin, pravastatin veya her iki ilacin kombinasyonunu alan hastalarda AH daha düşük bulunmuştur (Frears ve ark., 1999; Sterzer ve ark., 2001). Simvastatin üzerine yorumlar ise değişkendir. Ancak simvastatinin lipid düşürücü etkisinin büyüklüğü diğer iki statinden farklı olmadığı için, bu bulgular hem lovastatin hem de pravastatinin kolesterol biyosentezini azaltması dışında farklı bir mekanizma ile AH'yi önlediği öne sürülmektedir (Sterzer ve ark., 2001). Sonuç olarak görülmektedir ki plazma kolesterol düzeyi ile $\mathrm{AH}$ gelişme riski arasında oldukça önemli bir ilişkinin var- 
lığı kanıtlanmıştır. Bu bağlamda lipid düşürücü ilaçların AH'den koruyucu tedavideki rolü önem kazanmaktadır.

\section{Statinler ve Multipl Skleroz}

Statinlerin immün sistem üzerindeki düzenleyici özelliklerinin bulunmasıyla birlikte SSS'nin kronik otoimmün hastalığı olan Multipl skleroz (MS) üzerinde de faydalı etkileri olup olmadığını araştıran çalışmalar yapılmıştır. Halen MS tedavisinde immunmodülatör ve immunsupressan ilaçlar kullanılmaktadır. Ancak bu tedavi seçenekleri uygulama zorlukları (parenteral) ve pahalı olmasının yanı sıra, klinik üzerine kısmen etkilidirler ve yan etkileri oldukça fazladır (Hamamcıoğlu ve Vural, 2005).

MS'nin hayvan modeli olan deneysel otoimmün ensefalomyelit (EAE) ile yapılan çalışmalarda atorvastatinin $0.1,1.0,10 \mathrm{mg} / \mathrm{kg}^{\prime}{ }^{\prime} 1 \mathrm{k}$ kullanımı ile deney hayvanlarında çok hafif düzeylerde hastalık gelişmesi ve lovastatinin EAE'li ratlarda intraperitoneal verilmesinin hastalık üzerinde olumlu etki yapması bu grup ajanların tedavide kullanımını gündeme getirmiştir (Stanislaus ve ark., 2001). $\mathrm{Bu}$ bulgular çok ümit verici de olsa EAE'nin bir hayvan modeli olduğu ve ortaya çıkan hastalığın tam olarak insanlardaki MS'nin karşıllı̆ı olmadığı unutulmamalıdır.

Statinler ile yapılan birçok laboratuvar ve hayvan araştırmalarına rağmen statinlerin MS üzerinde etkili olduğuna dair çok az kanıt vardır. MS hastalarının başlangıç yaşı ortalama 32 iken kardiyovasküler nedenlerden ötürü korunma amaçlı statin kullanan hasta grubunun yaş ortalaması 57'dir (Hamamcıoğlu ve Vural, 2005). Bu farkl11ık nedeniyle, hiperkolesterolemili hastalarda statinlerin SSS inflamasyonu üzerindeki etkilerini değerlendirme amacıyla yapılmış araştırmaların sonuçları, MS'de kullanım açısından faydalı olamamaktadır.

Hiperkolesterolemi nedeni ile çalışmalarda kullanılmış çok sayıda ve değişik özellikte statin vardır. Hayvan deneylerinde statinin etkileri doza bağımlı olarak bulunmuştur. Bu nedenle düşük dozda kolesterol seviyesini düşüren statin grubu ajanlar bu dozlarda anti-inflamatuar etki sağlamayabilir. Birçok çalışmada statinlerin hiperkolesterolemi için onaylanmış dozlarında elde edilen kan seviyelerinin 25- 250 kat üstünde dozlar kullanılmıştır (Hamamc1oğlu ve Vural, 2005). Bununla birlikte statinlerle yapılmış dar kapsamlı birkaç çalışma vardır. Bu çalışmaların birinde, 30 relapsing-remitting MS (RRMS) hastas1, 3 ay süre ile herhangi bir tedavi almamış ve sonra 6 ay süre ile $80 \mathrm{mg}$ simvastatin tedavisi almış. 4,5 ve 6 . aylardaki beyin MRG yapılmış. Tedavi öncesi ve sonrası gadolinyum tutan lezyonlar incelenmiş ve sayılarında $\% 44$, hacimlerinde \%41 azalma tespit edilmiş. Tedavi sonunda herhangi bir ciddi yan etki tespit edilmemiş ve hastaların TH1 ve TH 2 sitokinlerini de içeren immün profilinde değişiklik saptanmamış (Vollmer ve ark., 2004). Her ne kadar bu çalışma, statinlerin klinik uygulamasında cesaret verici ilk adım olsa da çalışmaya alınan hasta grubunun sadece MRG'de kontrast tutan hastalardan seçilmesi, sonuçların çift kör kontrollü yapılmamas1 ve varılan yargıyı destekleyecek immünolojik verilerinin olmaması nedeni ile sonuçlar yeterli değildir.

Gözleme dayalı 7 hastadan oluşan diğer bir çalışmada Sena ve arkadaşları 12 ay süre ile lovastatin kullanı$\mathrm{m} 1$ sonras 14 hastada inflamatuar aktivitede azalma izlemesine rağmen 5 hastada beyin MRG'de T2 ağıllıklı serilerde lezyon sayılarında artış izlemiş (Sena ve ark., 2003). Bu veriler de sonuç itibariyle çelişkili olup bir sonuca ulaşabilmek için hasta sayısı yetersizdir.

MS ile ilgili çalışmalar değerlendirildiğinde daha çok laboratuvara dayalı olduğu ve klinik uygulamadan uzak olduğu görülmektedir. Takip amacı ile yapılan kısıtlı sayıdaki klinik uygulama ise bir sonuca varmak için yeterli değildir. MS'nin farklı seyreden birçok formu oldugu göz önüne alınacak olursa, statinlerin tüm hastaların beklentilerini karş1layabilecek özellikte olumlu etkilerinin varlığını gösterebilmek için daha çok plasebo kontrollü, randomize çalışmalara ihtiyaç vardır.

\section{Sonuç}

Statinlerin kolesterol düşürücü etkilerinin yanı sıra inflamasyon ve oksidasyon, hücre proliferasyonu, endotel fonksiyonları, koagülasyon ve trombosit sistemi üzerine de etkili olması, bu ilacın nöroloji pratiğinde kullanım alanını artırmaktadır. Statinlerin kardiyovasküler ve serebrovasküler olayları önlemedeki rolü artık çok iyi bilinmektedir. Ancak nörolojinin diğer alanlarındaki, özelliklede de MS ve demans tedavisindeki rolü ile ilgili prospektif çalışmalara ihtiyaç vardır.

\section{KAYNAKLAR}

Amarenco P., 2001. Hypercholesterolemia, lipid-lowering agents, and the risk for brain infarction. Neurology. 57, $35-44$.

Bales K, Verina T, Cummins D, Du Y, Dodel RC, Saura J, 1999. Apolipoprotein E is essential for amyloid deposition and neurotic degeneration in a mouse model of Alzheimer's disease. Proc Natl Acad Sci. 96, 15233-15238.

Björkhem I, Lütjohann D, Diczfalusy U., 1998. Cholesterol homeostasis in human brain turnover of 24S-hydroxycholesterol and evidence for a cerebral origin of most of this oxysterol in the circulation. J. Lipid Res. 39, 1594-1600.

Blauw GJ, Lagaay AM, Smelt AHM, Westendorp RG, 1997. Stroke, statins and cholesterol. A meta analysis of randomized, placebocontrolled, double-blind trials with HMG-CoA reductase inhibitors. Stroke. 28, 946-950. 
Cucchiara B, Kasner SE., 2001. Use of statins in CNS disorders. J Neurol Sci. 187, 81-89.

Delanty N, Vaughan CJ., 1997. Vascular effects of statins in stroke. Stroke. 28, 2315-2320.

Eastern Stroke and Coronary Heart Disease Collaborative Research Group., 1998. Blood pressure, cholesterol, and stroke in eastern Asia. Lancet. 352, 1801-1807.

Evans R, Emsley C, Gao S., 2000. Serum cholesterol, APOE genotype and the risk of Alzheimer disease. A population based study of African Americans. Neurology. 54, 240-242.

Frears ER, Stephens DJ, Walters CE., 1999. The role of cholesterol depletion in the biosynthesis of ßamyloid. Neuroreport. 16991705.

Gaw A., 2004. Genel uygulamada statinler. Bölüm 3; Statinler nelerdir ve işlevleri nelerdir. İkinci Bask1., 21-38.

Grundy SM., 1998. Statin trials and goals of cholesterol lowering therapy. Circulation 1998. 97, 1436-1439.

Hachinski V, Graffagnino C, Beaudry M, , Bernier G, Buck C, Donner A, ve ark., 1996. Lipids and stroke. Arch Neurol. 53, 303308.

Haley R., 2000. Is there a connection between the concentration of cholesterol circulating in plasma and the rate of neuritic plaque formation in Alzheimer disease. Arch Neurol. 57, 1410-1412.

Hamamcıŏlu K,Vural O., 2005. Statins For The Treatment of Multiple Sclerosis. J.Neurol. Sci.[Turk]. 22, 221-230.

Heart Protection Study Collaborative Group., 2004. Effect of cholesterol-lowering with simvastatin on stroke and other major vascular events in 20,536 people with cerebrovascular disease or other high-risk conditions. Lancet. 363, 757-767.

Iso H, Jacops DR, Wenworth D, , Neaton JD, Cohen JD, 1989. Serum cholesterol levels and six-year mortality from stroke in 350 977 men screened for the multiple risk factor intervention trial. N Engl J Med. 320, 904-910.

Kalmijn S, Feskens E, Launer L., 1996. Cerebrovascular disease, he apolipoprotein E4 allele and cognitive decline an a communitybased study of elderly men. Stroke. 27, 2230-2235.

Kayaalp SO., 1998. Tıbbi Farmakoloji. Hipolipidemik ilaçlar. 1. Cilt, 8. Baskı. Ankara, Hacettepe-Taş Kitapçılık Ltd.Şti. 567587.

Liao JK., 2002. Beyond lipid lowering: the role of statins in vascular protection. Int. J. Cardiol. 86, 5-18.

Plehn JF, Davis BR, Sacks FM, Rouleau JL, Pfeffer MA, Bernstein V, ve ark., 1999. Reduction of stroke incidence after myocardial infarction with pravastatin: the Cholesterol and Recurrent Events (CARE) Study. Circulation. 99, 216-223

Prospective studies collaborations., 1995. Cholesterol, diastolic blood pressure, and stroke: 13000 strokes in 450000 people in 45 prospective cohorts. Lancet. 346, 1647-1653

Rosenson RS, Tangey CC.,1998. Antiatherothrombotic properties of statins: implications for cardiovascular event reduction. JAMA. $27920,1643-1650$.

Rockwood K, Kirkland S, Hogan DB., 2002. Use of lipid-lowering agents, indication bias, and the risk of dementia in commuitydwelling elderly people. Arch Neurol. 59, 223-227.

Sena A, Pedrosa R, Morais MG., 2003. Therapeutic potential of lovastatin in multiple sclerosis. J. Neurol. 250, 754-755.

Shepherd J, Cobbe SM, Ford I, Isles CG, Lorimer AR, MacFarlane PW, ve ark., 1995. Prevention of coronary heart disease with pravastatin in men with hypercholesterolemia. N Engl J Med. 333, 1301-1307.

Simons M, Keller P, Dichgans J., 2000. Cholesterol and Alzheimer's disease: Is there a link. Neurology. 57,1089-1093.

SPARCL Investigators. 2006. High-dose atorvastatin after stroke or transient ischemic attack. N Engl J Med 2006; 355, 549-559.

Stanislaus R, Singh AK, Singh I., 2001. Lovastatin treatment decreases mononuclear cell infiltration into the CNS of Lewis rats with experimental allergic encephalomyelitis. J Neurosci Res. 66,155-162.

Sterzer P, Meintzschel F, Rosler A., 2001. Pravastatin improves cerebral vasomotor reactivity in patients with subcortical small vessel disease. Stroke. 32, 2817-2820.

Takemoto M, Liao JK., 2001. Pleiotropic effects of 3-hydroxy-3-methylglutaryl coenzyme A reductase inhibitors. Arterioscler Thromb Vasc Biol. 21,1712-1719.

TenDam VH, Bollen EL, Westendorp RG., Role of statins in prevention of stroke and dementia. Ned Tijdschr Geneeskd. 145,1918- 
1921.

Warshafsky S, Packard D, Marks SJ, Sachdeva N, Terashita DM, Kaufman G, ve ark., 1999. Efficacy of 3-hydroxy-3- methylglutaryl coenzyme a reductase inhibitors for prevention of stroke. J Gen Intern Med. 14,763-774.

Vaughan CJ, Murphy MB, Buckley BM., 1998. Statins do more than just lower cholesterol. Lancet. 348,1079-1082.

Vaughan CJ, Delanty N., 1999. Neuroprotective properties of statins in cerebral ischemia and stroke. Stroke. 30, 1969-1973.

Vaughan CJ, Delanty N, Basson CT., 2001. Do statins afford neuroprotection in patients with cerebral ischemia and stroke. CNS Drugs. 15, 589-596.

Vollmer T, Key L, Durkalski V, Tyor W, Corboy J, Markovic-Plese S, ve ark., 2004. Oral simvastatin treatment in relapsing-remitting multiple sclerosis. Lancet. 363, 1607-1608

Yano K, Reed DM, MacLean CJ., 1989. Serum cholesterol and hemorrhagic stroke in the Honolulu Heart Program. Stroke. 20, 4605 